SCIENTIFIC CORRESPONDENCE

\title{
Intraocular pressure after intravitreal injection of triamcinolone acetonide
}

\author{
J B Jonas, I Kreissig, R Degenring
}

Br J Ophthalmol 2003;87:24-27

Aim: To investigate the intraocular pressure (IOP) response after intravitreal injections of triamcinolone acetonide as treatment of intraocular neovascular or oedematous diseases.

Methods: The prospective consecutive non-comparative interventional case series study included 71 patients $(75$ eyes) with progressive exudative age related macular degeneration ( $n=64$ eyes) or diffuse diabetic macular oedema ( $n=11$ eyes), who received an intravitreal injection of $25 \mathrm{mg}$ triamcinolone acetonide. Mean follow up time was 6.86 (SD 2.52) months (range 3.1-14.47 months).

Results: IOP increased significantly $(p<0.001)$ from $15.43(3.26) \mathrm{mm} \mathrm{Hg}$ preoperatively to a mean maximum of 23.38 (8.37) mm Hg (range 13-64 mm Hg) postoperatively. An IOP rise to values higher than $21 \mathrm{~mm} \mathrm{Hg}$ was observed in $39(52 \%)$ eyes. Elevation of IOP occurred about 2 months after the injection. Preoperative predictive factor for the rise in IOP was younger age $(p=0.013)$. It was statistically independent of refractive error, presence of diabetes mellitus, and indication for the injection. In all but one eye, IOP could be lowered to the normal range with topical medication, without development of glaucomatous optic nerve head changes. In the eyes with an elevation of IOP, IOP normalised about 6 months after the injection, without further medication. Eyes undergoing repeatedly intravitreal injections of triamcinolone acetonide showed only an elevation of IOP, if after the first injection a rise of IOP had occurred.

Conclusions: After intravitreal injections of $25 \mathrm{mg}$ of triamcinolone acetonide, an IOP elevation can develop in about $50 \%$ of eyes, starting about $1-2$ months after the injection. In the vast majority, IOP can be normalised by topical medication, and returns to normal values without further medication about 6 months after the injection.

R ecent clinical and experimental studies have suggested that the intravitreal injection of triamcinolone acetonide may be a therapeutic option for the treatment of intraocular neovascular, oedematous, or inflammatory diseases. ${ }^{1-33}$ Taking into account that the eye comprises only $0.01 \%$ of the whole ocular volume, it makes sense to try treating intraocular diseases by intravitreal injections, instead of oral medication. The latter will need a higher dosage, with a higher number of systemic side effects, to reach the same intraocular concentration of the drug as if the medication was applied intraocularly. One of the ocular side effects of corticosteroids is the elevation of intraocular pressure (IOP) leading to a secondary chronic open angle glaucoma. ${ }^{34-36}$ Since previous studies examined the rate and amount of elevation of IOP after topical application of cortisone leading to much lower intraocular concentrations of steroids than if the steroids were injected intravitreally, we aimed to evaluate the response of IOP after the intravitreal injection of corticosteroids. ${ }^{34-36}$ Knowledge about the IOP response to the intravitreal injection of corticosteroids may be important for future discussions, under which clinical conditions an intraocular injection of triamcinolone acetonide may be considered as therapeutic approach.

\section{PATIENTS AND METHODS}

The prospective interventional case series study included 71 patients ( 75 eyes) ( 51 women, 20 men; 37 right eyes, 38 left eyes) who consecutively received an intravitreal injection, and of whom 12 patients repeatedly received an intravitreal injection, of $25 \mathrm{mg}$ triamcinolone acetonide in topical anaesthesia, and who had a minimal follow up time of 3 months. Reason for the intravitreal injection of triamcinolone acetonide were progressive decrease of visual acuity due to exudative age related macular degeneration with subfoveal neovascularisation $(n=64$ eyes $)$, or diffuse diabetic macular oedema $(n=11$ eyes). Four $(5.4 \%)$ patients received the intravitreal cortisone injection in both eyes, with a time interval of 3.5-5 months between the injections. Refractive error ranged between -5.00 dioptres and +7.63 dioptres (mean +1.28 (SD 2.05) dioptres; median +1.25 dioptre). Mean age was 76.83 (7.15) years (range 60.1-100.1 years; median, 77.20 years). All patients were fully informed about the experimental character of the therapy. All patients signed an informed consent. The ethics committee of the university had approved the study. The study followed the tenets of the Declaration of Helsinki.

Six (8.5\%) patients had chronic open angle glaucoma before inclusion into the study. Arterial hypertension was present in $26(36.6 \%)$ patients, and diabetes mellitus had been detected in $17(23.9 \%)$ patients before the intravitreal injection. Two $(2.8 \%)$ patients had a history of an elevation of IOP during topical or systemic steroid treatment before inclusion in the study.

All patients received an intravitreal injection of $25 \mathrm{mg}$ of crystalline triamcinolone acetonide in $0.2 \mathrm{ml}$ Ringer's solution under sterile conditions in the operating theatre. The solution was prepared by the hospital's pharmacy removing the solvent agent. Using the operation microscope, the injection was transconjunctivally carried out under topical anaesthesia after a paracentesis had been performed to decrease the volume of the globe. Using applanation tonometry, IOP was determined before, and in intervals of 4 weeks after, the injection.

Mean follow up time was 6.86 (2.52) months (median 6.40 months), with a minimum of 3 months after the first injection (range 3.1-14.47 months).

For interindividual comparisons, only one randomly selected eye per patient was taken for statistical analysis. For intraindividual bilateral comparison, the four patients with both eyes treated were included in the analysis.

\section{RESULTS}

Intraocular pressure increased significantly $(\mathrm{p}<0.001)$ from 15.43 (3.26) mm Hg (range 8-28 mm Hg; median, 16 mm Hg) 
Table 1 Intraocular pressure (IOP) (mean (SD)) before, and after, the intravitreal injection of $25 \mathrm{mg}$ of triamcinolone acetonide; $p$ value: difference between the postoperative value and the preoperative value

\begin{tabular}{llll}
\hline & $\begin{array}{l}\text { Number } \\
\text { of eyes }\end{array}$ & IOP $(\mathrm{mm} \mathrm{Hg})$ & $\mathrm{p}$ Value \\
\hline Follow up (months) & 71 & $14.89(2.92)$ & \\
Preoperative & 72 & $14.73(4.00)$ & 0.42 (ns) \\
1 day postoperative & 66 & $16.14(3.55)$ & 0.046 \\
1 week postoperative & 63 & $17.60(4.77)$ & $<0.001$ \\
1 month postoperative & 60 & $18.53(6.75)$ & $<0.001$ \\
2 months postoperative & 63 & $18.35(6.75)$ & $<0.001$ \\
3 months postoperative & 50 & $18.50(5.72)$ & $<0.001$ \\
4 months postoperative & 36 & $19.39(6.21)$ & $<0.001$ \\
5 months postoperative & 37 & $20.83(9.61)$ & $<0.001$ \\
6 months postoperative & 19 & $17.26(4.04)$ & $0.130(\mathrm{~ns})$ \\
7 months postoperative & 9 & $19.78(6.87)$ & 0.107 (ns) \\
8 months postoperative & 9 & & \\
\hline
\end{tabular}

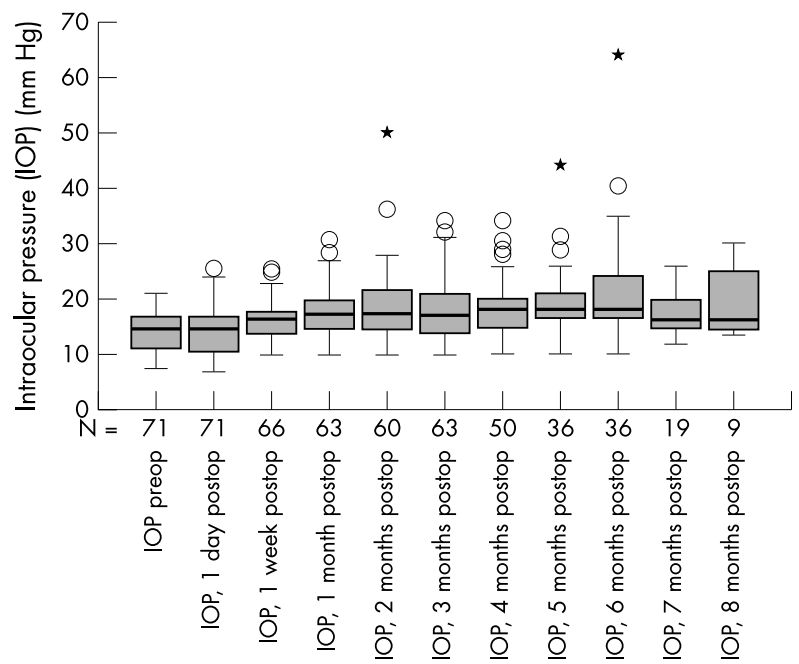

Figure 1 Box plots showing the distribution of intraocular pressure measurements (IOP) before and after the intravitreal injection of 25 $\mathrm{mg}$ of triamcinolone acetonide.

to a mean maximum of 23.38 (8.37) $\mathrm{mm} \mathrm{Hg}$ (range 13-64 mm $\mathrm{Hg})$ postoperatively. The differences between the IOP measurements before the injection and the postoperative examinations were significant $(\mathrm{p}<0.05)$ for the examinations performed 1 week or later after the injection (Table 1, Figs 1 and 2 ). A rise in IOP to values higher than $21 \mathrm{~mm} \mathrm{Hg}$ was observed in $39(52 \%)$ eyes. The elevation of IOP usually occurred after about 1-2 months (Fig 2).

Four $(66.6 \%)$ of the six patients with the preoperative diagnosis of chronic open angle glaucoma demonstrated an IOP rise compared to $31(48.6 \%)$ of the remaining 65 patients without the preoperative diagnosis of glaucoma. Perhaps because of the relatively small number of patients in the subgroups, the difference was statistically not significant $\left(p=0.32 ; \chi^{2}\right.$ test). The post-injection rise of IOP to values higher than $21 \mathrm{~mm} \mathrm{Hg}$ was statistically independent of refractive error $(p=0.35)$, sex $(p=0.30)$, presence of diabetes mellitus $(p=0.37)$, and indication for the injection (age related macular degeneration versus diabetic macular oedema) $(p=0.44)$. The patients with a rise of IOP were significantly $(\mathrm{p}=0.013)$ younger than the patients without an elevation of IOP beyond $21 \mathrm{~mm} \mathrm{Hg}$ (74.84 (6.77) years versus 78.99 (7.0) years). With a minimal follow up of 3 months, the occurrence of a rise of IOP was statistically independent of the length of the follow up period $(\mathrm{p}=0.31)$.

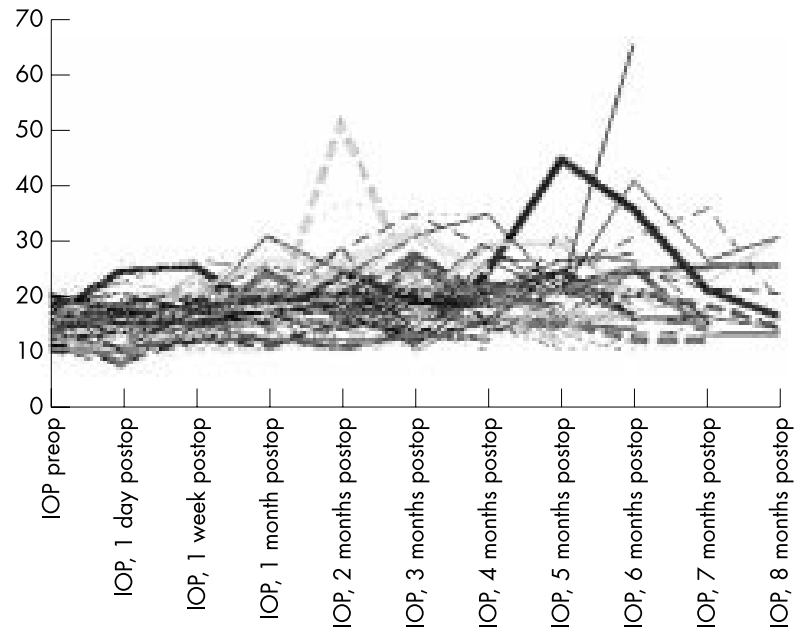

Figure 2 Scatter plot showing the distribution of individual intraocular pressure measurements (IOP) before and after the intravitreal injection of $25 \mathrm{mg}$ of triamcinolone acetonide.

Within the group of patients with a postoperative rise of IOP, in all but one eye IOP could be lowered to normal levels with topical medication, without developing glaucomatous optic nerve head changes. ${ }^{37}$ One eye with a preinjection diagnosis of primary open angle glaucoma developed IOP values up to $60 \mathrm{~mm} \mathrm{Hg}$ after the injection (Fig 2). Despite maximal medical therapy, the IOP remained high requiring filtering surgery. After a conventional penetrating glaucoma surgery, IOP ranged between 5 and $12 \mathrm{~mm} \mathrm{Hg}$. In the other eyes with an elevation of IOP, IOP normalised about 6 months after the injection, without further medication taken.

All eyes which developed a secondary ocular hypertension after a second intravitreal injection of triamcinolone acetonide had also shown a rise in IOP after the first intravitreal injection. Those eyes without a pressure rise after the first injection did not develop increased IOP after a second injection.

Three $(75 \%)$ of the four patients who received an intravitreal injection of triamcinolone acetonide into both eyes with a time interval of 3.5-5 months between the injections, developed in both eyes an ocular hypertension at about the same time after each injection. The remaining patient with a bilateral injection did not develop elevated IOP values higher than $21 \mathrm{~mm} \mathrm{Hg}$ in either of his treated eyes.

\section{DISCUSSION}

Intraocular neovascular diseases, such as exudative age related macular degeneration and proliferative diabetic retinopathy, oedematous diseases of the retina, such as diffuse diabetic macular oedema and persistent cystoid macular oedema due to various other diseases, and chronic intraocular inflammation are some of the leading causes of impaired vision. The intraocular proliferation of cells is often accompanied and stimulated by intraocular inflammation, and macular oedema can be caused by a damaged blood-retinal barrier due to capillary leakage. Corticosteroids have long been known to tighten up blood vessels resulting in a decrease of vessel leakage and, depending on the concentration, to suppress proliferation of cells. Consequently, steroids have been used for the treatment of various ocular diseases, applied either topically or systemically. Often, however, the intraocular concentrations of corticosteroids were not sufficiently high, or the systemic side effects were too serious, to effectively treat the ocular disorder.

Taking into account that the eye comprises only $0.01 \%$ of the entire body volume, and considering that for achieving a high concentration of a drug at its site of action, it is best to 
apply it directly in the area of required action, Machemer, Graham, Peyman, and other researchers studied the possibility of injecting corticosteroids directly into the eye, in experimental settings in animals as well as in selected clinical situations in patients. ${ }^{19-21}$ Additionally, observations of clinical outcome after accidental intraocular injections of cortisone have been published. ${ }^{38}{ }^{39}$ In experimental investigations, Machemer and coworkers had observed that the vehicle, and not the crystalline corticosteroid itself, can be toxic to intraocular tissues. ${ }^{40}{ }^{41}$ Correspondingly, a direct toxicity of high intraocular concentrations of corticosteroids has not been detected in ongoing studies so far. The presented studies demonstrated that a single intraocular injection of triamcinolone acetonide may potentially be helpful as adjunctive treatment of proliferate diabetic retinopathy, clinically significant diabetic macular oedema, neovascular glaucoma, and pre-phthisical ocular hypotony. ${ }^{1-18}$ In the latter studies, as suggested by Machemer, a crystalline corticosteroid (triamcinolone acetonide) was taken which remains in the eye for 2-5 months after a single intravitreal injection, in contrast with a soluble corticosteroid which is washed out of the eye within 24 hours after intraocular application. ${ }^{42}$

One of the major side effects, which are most often discussed in combination with an intravitreal injection of triamcinolone acetonide, is a steroid induced elevation of IOP. $^{34-36}$ The results of the present study showed that a rise of IOP to values higher than $21 \mathrm{~mm} \mathrm{Hg}$ can be expected to occur in about $50 \%$ of the eyes treated. A predictive factor for the rise of IOP may have been the presence of glaucoma before the injection. This relation, however, was statistically not significant. But a statistically significant relation was found for the younger age with a post-injection rise in IOP. Other parameters, such as sex and refractive error of the patient did not show a marked influence on frequency and amount of the elevation of IOP. Interestingly, the presence of diabetes mellitus did not demonstrate a marked influence $(p=0.37)$ on the rate of a postoperative elevation of IOP.

From a clinical point of view it may be important that in all but one eye, the IOP could be controlled by topical antiglaucomatous treatment, or returned to normal values after the intravitreal steroid crystals had resolved about 6 months after the injection. It may also be of importance that, as could be expected, a rise in IOP after a second intravitreal injection did not occur, if after the first injection, the IOP had remained within the normal range. Also, as to be expected, both eyes of the same patient reacted in a similar way, if both eyes received an intravitreal injection.

In contrast with other clinical studies reporting on the intravitreal injection of triamcinolone acetonide, the dosage used in the present investigation was about six times higher (25 mg versus $4 \mathrm{mg}$ ). ${ }^{2-68} 914151718$ 28-30 33 Without starting a discussion on the clinical usefulness and necessity to use a remarkably higher dosage than in other studies, the results of the present investigation demonstrate that also with this high dosage of intravitreal triamcinolone acetonide, the steroid induced elevation in IOP can usually be controlled without development of a major damage to the optic nerve.

In conclusion, the data of the present study suggest that the intravitreal injection of triamcinolone acetonide in a dosage of $25 \mathrm{mg}$ leads to a secondary ocular hypertension in about $50 \%$ of the eyes treated; that the rise of IOP is reversible about 6 months after the injection; that the rise of IOP can usually be controlled by topical antiglaucomatous medication; and that the steroid induced ocular hypertension may thus not be a major contraindication against the use of intravitreal triamcinolone acetonide as treatment trial of intraocular neovascular or oedematous diseases.

Proprietary interest: none.

\section{Authors' affiliations}

J B Jonas, I Kreissig, R Degenring, Department of Ophthalmology, Faculty of Clinical Medicine Mannheim of the University Heidelberg, Germany

Correspondence to: Dr J Jonas, Universitäts-Augenklinik, Theodor-Kutzer-Ufer 1-3, 68167 Mannheim, Germany;

Jost.Jonas@ma.augen.uni-heidelberg.de

Accepted for publication 24 July 2002

\section{REFERENCES}

1 Machemer R, Sugita G, Tano Y. Treatment of intraocular proliferations with intravitreal steroids. Trans Am Ophthalmol Soc 1979;77:171-80.

2 Penfold P, Gyory J, Hunyor A, et al. Exudative macular degeneration and intravitreal triamcinolone. A pilot study. Aust NZ J Ophthalmol 1995;23:293-8.

3 Machemer R. Five cases in which a depot steroid (hydrocortisone acetate and methylprednisolone acetate) was injected into the eye. Retina 1996;16:166-7.

4 Challa JK, Gillies MC, Penfold PL, et al. Exudative macular degeneration and intravitreal triamcinolone: 18 month follow up. Aust NZ J Ophthalmol 1998;26:277-81.

5 Wingate RJ, Beaumont PE. Intravitreal triamcinolone and elevated intraocular pressure. Aust N Z J Ophthalmol 1999;27:431-2.

6 Jaffe GJ, Ben-nun J, Guo H, et al. Fluocinolone acetonide sustained drug delivery device to treat severe uveitis. Ophthalmology 2000; 107:2024-33.

7 Jonas JB, Hayler JK, Panda-Jonas S. Intravitreal injection of crystalline cortisone as adjunctive treatment of proliferative vitreoretinopathy. $\mathrm{Br} J$ Ophthalmol 2000;84:1064-7.

8 Danis RP, Ciulla TA, Pratt LM, et al. Intravitreal triamcinolone acetonide in exudative age-related macular degeneration. Retina 2000:20:244-50.

9 Kivilcim M, Peyman GA, El-Dessouky ES, et al. Retinal toxicity of triamcinolone acetonide in silicone-filled eyes. Ophthalmic Surg Lasers 2000;31:474-8.

10 Jonas JB, Hayler JK, Söfker A, et al. Regression of neovascular iris vessels by intravitreal injection of crystalline cortisone. J Glaucoma $2001 ; 10: 284-7$

11 Jonas JB, Hayler JK, Söfker A, et al. Intravitreal injection of crystalline cortisone as adjunctive treatment of proliferative diabetic retinopathy. Am J Ophthalmol 2001;131:468-71.

12 Jonas JB, Söfker A. Intraocular injection of crystalline cortisone as adjunctive treatment of diabetic macular edema. Am J Ophthalmol $2001 ; 132: 425-7$

13 Jonas JB, Hayler JK, Panda-Jonas S. Intravitreal injection of crystalline cortisone as treatment of pre-phthisical ocular hypotony. Graef Arch Clin Exp Ophthalmol 2001;239:464-5.

14 Antcliff RJ, Spalton DJ, Stanford MR, et al. Intravitreal triamcinolone for uveitic cystoid macular edema:an optical coherence tomography study. Ophthalmology 2001;108:765-72.

15 Young S, Larkin G, Branley M, et al. Safety and efficacy of intravitreal triamcinolone for cystoid macular edema in uveitis. Clin Exp Ophthalmol $2001 ; 29: 2-6$

16 Reinhard T, Sundmacher R. Adjunctive intracameral application of corticosteroids in patients with endothelial immune reactions after penetrating keratoplasty. A pilot study. Transpl Int 2002:15:81-8.

17 Greenberg PB, Martidis A, Rogers AH, et al. Intravitreal triamcinolone acetonide for macular oedema due to central retinal vein occlusion. $\mathrm{Br} J$ Ophthalmol 2002;86:247-8

18 Ranson NT, Danis RP, Ciulla TA, et al. Intravitreal triamcinolone in subfoveal recurrence of choroidal neovascularisation after laser treatment in macular degeneration. Br J Ophthalmol 2002;86:527-9.

19 Graham RO, Peyman GA. Intravitreal injection of dexamethasone. Treatment of experimentally induced endophthalmitis. Arch Ophthalmol 1974:92:149-54.

20 Tano $Y$, Sugita $G$, Abrams $G$, et al. Inhibition of intraocular proliferation with intravitreal corticosteroid. Am J Ophthalmol 1980;89:131-6.

21 Tano Y, Chandler D, Machemer R. Treatment of intraocular proliferation with intravitreal injection of tramcinolone acetonide. Am J Ophthalmol 1980:90:810-16

22 Ishibashi T, Miki K, Sorgente N, et al. Effects of intravitreal administration of steroids on experimental subretinal neovascularization in the subhuman primate. Arch Ophthalmol 1985;103:708-1 1

23 Kwak HW, D'Amico DJ. Evaluation of the retinal toxicity and pharmacokinetics of dexamethasone after intravitreal injection. Arch Ophthalmol 1992;110:259-66.

24 Antoszyk AN, Gottlieb JL, Machemer R, et al. The effects of intravitreal triamcinolone acetonide on experimental pre-retinal neovascularization. Graefes Arch Clin Exp Ophthalmol 1993;231:34-40.

25 Danis RP, Bingaman DP, Yang Y, et al. Inhibition of preretinal and optic nerve head neovascularization in pigs by intravitreal triamcinolone acetonide. Ophthalmology 1996;103:2099-104.

26 Berger AS, Cheng CK, Pearson PA, et al. Intravitreal sustained release corticosteroid-5-fluoruracil conjugate in the treatment of experimental proliferative vitreoretinopathy. Invest Ophthalmol Vis Sci 1996;37:2318-25. 
27 Yang CS, Khawly JA, Hainsworth DP, et al. An intravitreal sustained-release triamcinolone and 5-fluorouracil codrug in the treatment of experimental proliferative vitreoretinopathy. Arch Ophthalmol 1998:116:69-77.

28 Jaffe GJ, Yang $\mathrm{CH}$, Guo H, et al. Safety and pharmacokinetics of an intraocular fluocinolone acetonide sustained delivery device. Invest Ophthalmol Vis Sci 2000;41:3569-75.

29 Penfold PL, Wen L, Madigan MC, et al. Triamcinolone acetonide modulates permeability and intercellular adhesion molecule-1 (ICAM-1) expression of the ECV304 cell line:implications for macular degeneration. Clin Exp Immunol 2000;1 121:458-65.

30 Penfold PL, Wong JG, Gyory J, et al. Effects of triamcinolone acetonide on microglial morphology and quantitative expression of MHC-II in exudative age-related macular degeneration. Clin Experiment Ophthalmol 2001;29:188-92.

31 Ciulla TA, Criswell MH, Danis RP, et al. Intravitreal triamcinolone acetonide inhibits choroidal neovascularization in a laser-treated rat model. Arch Ophthalmol 2001;119:399-404.

32 Penn JS, Rajaratnam VS, Collier RJ, et al. The effect of an angiostatic steroid on neovascularization in a rat model of retinopathy of prematurity. Invest Ophthalmol Vis Sci 2001;42:283-90.

33 Martidis A, Duker JS, Greenberg PB, et al. Intravitreal triamcinolone for refractory diabetic macular edema. Ophthalmology 2002;109:920-7.
34 Becker B, Bresnick G, Chevrette L, et al. Intraocular pressure and its response to topical corticosteroids in diabetes. Arch Ophthalmol 1966:76:477-83

35 Becker B, Ballin N. Glaucoma and corticosteroid provocative testing. Arch Ophthalmol 1965;74:621-4.

36 Bigger JF, Palmberg PF, Zink H, et al. Sensitivity to glucocorticoids in primary open-angle glaucoma. N Engl J Med 1972;287:992.

37 Jonas JB, Budde WM, Panda-Jonas S. Ophthalmoscopic evaluation of the optic nerve head. Surv Ophthalmol 1999;43:293-320.

38 Giles CL. Bulbar perforation during periocular injection of corticosteroids. Am J Ophthalmol 1974;77:438-41.

39 McLean EB. Inadvertent injection of corticosteroid into the choroidal vasculature. Am J Ophthalmol 1975;80:835-7.

40 McCuen BW 2d, Bessler M, Tano Y, et al. The lack of toxicity of intravitreally administered triamcinolone acetonide. Am J Ophthalmol 1981;91:785-8.

41 Hida T, Chandler D, Arena JE, et al. Experimental and clinical observations of the intraocular toxicity of commercial corticosteroid preparations. Am J Ophthalmol 1986;101:190-5.

42 Schindler RH, Chandler DB, Thresher R, et al. The clearance of intravitreal triamcinolone acetonide. Am J Ophthalmol 1982;93:415-17.

\section{Video Reports (www.bjophthalmol.com)}

- Capsule staining and mature cataracts: a comparison of indocyanine green and trypan blue dyes. D F Chang

- Pearls for implanting the Staar toric IOL. D F Chang

- An intraocular steroid delivery system for cataract surgery. D F Chang

- Evaluation of leucocyte dynamics in mouse retinal circulation with scanning laser ophthalmoscopy. $H X_{U}$, A Manivannan, G Daniels, J Liversidge, P F Sharp, J V Forrester, IJ Crane

- Dipetalonema reconditum in the human eye. T Huynh, J Thean, R Maini

- Surgical revision of leaking filtering blebs with an autologous conjunctival graft. K Taherian, A Azuara-Blanco

- Thixotropy: a novel explanation for the cause of lagophthalmos after peripheral facial nerve palsy. $M$ Aramideh, J H T M Koelman, P P Devriese, F VanderWerf, J D Speelman 